\title{
Neurofilament Heavy Polypeptide
}

National Cancer Institute

\section{Source}

National Cancer Institute. Neurofilament Heavy Polypeptide. NCI Thesaurus. Code C88040.

Neurofilament heavy polypeptide (1026 aa, $112 \mathrm{kDa}$ ) is encoded by the human NEFH gene. This protein plays a role in both the establishment and maintenance of axonal and dendritic structures. 